\section{ECONOMICS}

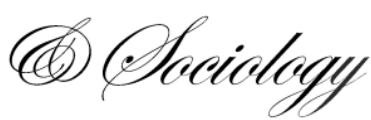

\title{
ROLE OF MICROFINANCE INSTITUTIONS FOR DEVELOPING WOMEN ENTREPRENEURSHIP - THE CASE STUDY OF KOSOVO
}

\author{
Jehona Shkodra \\ Faculty of Agriculture and \\ Veterinary, \\ University of Prishtina, Kosovo \\ E-mail:jehona.shkodra@uni- \\ pr.edu \\ ORCID 0000-0001-9207-4098
}

\section{Prespa Ymeri \\ University of Prishtina, Faculty of Agriculture and Veterinary, \\ Kosovo \\ E-mail:prespa.ymeri@uni-pr.edu ORCID 0000-0002-3521-9825 \\ Lindita Ibishi \\ Faculty of Agriculture and \\ Veterinary, \\ University of Prishtina, Kosovo \\ E-mail: \\ linditaibishi1@,outlook.com}

Received: January, 2020

1st Revision: July, 2020

Accepted: March, 2021

DOI: $10.14254 / 2071$ -

789X.2021/14-1/8
ABSTRACT. Microfinance institutions (MFIs) are the only door of assistance to low-income people and businesses with poor financial performance. Women also fall into this category, as most of them have low incomes and the only way to ensure their own and their families' well-being is to start a business. Given the many criteria of commercial banks, for women entrepreneurs MFIs are often the only option of financial lending. The extent to which MFIs have influenced the development of women businesses in Kosovo will be understood from the research conducted with 200 women entrepreneurs in Kosovo. Interviews were carried out face to face with the PAPI (pencil and paper interview) survey methodology used during April-June, 2019. The data obtained from the survey has been then processed in statistical software SPSS 21.0 The research applies three econometric models to identify the effects of MFI loans on the success of women businesses. The success of women enterprises is assessed using three performance measurements: fixed assets, income and household expenditures. The results of this study explain that loans from MFIs effect performance of women's businesses in positive way using fixed assets, income and household expenses.
JEL Classification: B54, C5, G21
Keywords: women entrepreneurship, loan, microfinance institutions, Kosovo.

\section{Introduction}

Microfinance as a financial service provides access to financial services for low-income and unemployed people. It has been quite successful in reducing poverty and promoting economic development (Shkodra, 2019). This is also argued in (Fidrmuc \& Kostagianni, 2015) who found that allowing for the IMF assistance to affect growth with a lag is enough to obtain a positive impact on growth. Microfinance is a powerful tool for self-empowering poor people, mostly women, worldwide and in developing countries in particular. Microfinance activities 
can give these people opportunities to get out of poverty. The problem of women having less access to credit was given special attention at the First International Conference of Women in Mexico back in 1975 (Bonfiglioli et al., 2016). However, even today we still have the problem of less access to credit for women entrepreneurs (Alkire et al., 2013), which is thought to be one of the major obstacles for them to pursue their income-generating activities (Mahmud et al., 2019). Microfinance services lead to the empowerment of women by positively influencing their decision-making power at both household and socioeconomic levels. Numerous studies about women entrepreneurs have proven their excellence in business, in relation to economic growth and development, as well as in relation to sustainability and sustainable peace (Fetsch, Jackson \& Wiens, 2015). Women have been found to be better at using credit than men (Khaleque, 2018). At the same time, many poor rural women lack ownership and control over property such as land (Khan et al., 2016; Uddin et al., 2016).

Microfinance plays a big role in gender development strategies due to its direct relationship between women and poverty alleviation. Since women spend most of their income on their families, especially children's needs, education, healthcare, clothing and financial resources not only empower women, but also enable them to access property, education and decision making.

Around the world, women's engagement during past three decades regarding workforce has produced great transformations in the organization of families, society, the economy and urban life. Since the late 1950s to the present day, women's economic activities have grown steadily but not with the right intensity though.

Women have always played an active role in their local economies. In most cases, women not only produce food but also trade giving them a developed knowledge of local markets and consumers.

\section{Literature review}

According to recent data, the global population growth by 2050 is projected to increase dramatically (Shkodra, J. \& Shkodra, L. 2018). On the other hand, of the 1.3 billion people worldwide who live in extreme poverty, approximately $70 \%$ of them are women. Another negative point relates to the statistics from the International Monetary Fund (2019), which show that, worldwide, women earn $63 \%$ less than men, yet they spend three times as many hours in unpaid labour. Therefore, empowering women means allowing women to survive, and live a life of respect, dignity, self-esteem, and self-confidence, while helping them on making their own decisions. Nobel Laureate Amartaya Sen (1993) explained that the freedom to run different types of businesses reflects one's ability. A person's ability depends on different factors, including personal characteristics and social adjustments. Malhotra, A., et al. (2002) constructed a list of the most commonly used dimensions of women's empowerment, based on frameworks developed by authors in various areas of the social sciences. Allowing for overlap, these frameworks suggest that women's empowerment must occur across multiple dimensions, including: economic, socio-cultural, family/interpersonal, legal, political, and psychological. The World Bank defines empowerment as "the process of enhancing the capacity of individuals or groups to make choices and transform these choices into the actions and outcomes desired". Swain, R. B., \& Wallentin, F. Y. (2009) in their article "Do Microfinance Empower Women?", concluded that "The results strongly demonstrate that on average there is a significant increase in the empowerment of women in the Microfinance Programs". Another view of women's empowerment argues that it must occur in many aspects: economic, socio-cultural, family/interpersonal, legal, political, and psychological (Malhotra, A., et al. 2002). These 
include a wide range of factors, and thus business women can be empowered within one of said sub-domains.

MFIs are adequate for micro credits and micro credits provided encouragement to women entrepreneurs for few decades and this is argued by many researchers who showed that micro credit programs play a significant role in accelerating women's income (Mahmud, K. T. et al., (2019); Mahmud \& Bidisha, 2018; Ferdousi, 2012, 2015; Bashar \& Rashid, 2012).

Social capital and networks, the ability to make an effective living, and community development choices are all associated with empowerment (Ferdousi, F., \& Mahmud, P., 2019; Krishna, 2003; Grootaert, 2003). Numerous studies have indicated that women are particularly motivated to start their own businesses in hopes of achieving a better balance between work and family (Hughes, 2005; Swapna, K., 2017 Quagrainie, F.A., et. al., 2018). Also Brahmachary, A. (2017) analysed the major problems related to women-owned small businesses in India and the role of microfinance groups to accelerate such businesses providing small finance.

\section{Research methodology}

The research was conducted by interviewing 200 women entrepreneurs in Kosovo, face to face interview with PAPI (Pencil and paper interview) survey methodology during April June 2019.

For data analysis, SPSS 21.0 was used, alongside the descriptive statistical method. In the final phase, the results were processed and presented in the form of tables.

The aim of this study is focus on the role of MFI for contributing the developing women entrepreneurship. Meantime, the success of women entrepreneurship is measured in terms of improvements in income, fixed assets and expenditures. The research used three econometric models in focusing on the effectiveness of credit in contributing to the success of women businesses. The success was measured through the performance of women businesses, including fixed assets, income and expenditures. Moreover, the research study concentrated on three components which are assumed to contribute positively to the performance of women businesses, namely financing, firm's characteristics and household's characteristics.

The study addresses the following two questions that define the role of MFIs for the development of women entrepreneurs:

i. What are the determinants of women entrepreneurship success in terms of their performance measured by income, fixed assets and expenses?

ii. Are there other factors besides MFIs products of the women's entrepreneurship; such as type of business and household characteristics which contributes significantly to the success achieved by microenterprise owners in terms of their income, fixed assets, and expenditure?

Women Entrepreneurs play an important role in the development of entrepreneurship, as with their development they also contribute to the impact of entrepreneurship development in the country. The entrepreneurship mainly used: age, marital status, and educational (Table 1 shows descriptions of each variable). These typically are also assumed enable to give contribution for women entrepreneurship performance.

The research selects four factors that may affect the success of the women's entrepreneurship, financing, namely, entrepreneur characteristics, firm's characteristics, and household characteristics. These four factors represent the independent variables in this study.

We used the before and after method in examining the effectiveness of loans in relation to the performance of women businesses through fixed assets, income and expenses before and after receiving a loan from the MFI. The before and after the method is applied when the data 
obtained from the research are period $\mathrm{T}=2$, and it is applicable the comparison of value of the dependent variable in the second period with its value in the first period of time.

The empirical models are presented below:

Equation 1 presents the first model for income:

$$
\text { Income }_{i}=\alpha+\sum_{i=1}^{4} \beta_{2} \text { Age }_{i}+\sum_{i=1}^{3} \beta_{3} \text { Status }_{i}+\sum_{i=1}^{4} \beta_{4} E d u_{i}+\sum_{i=1}^{6} \beta_{5} \text { TB } B_{i}+\beta_{6} \text { Loan }_{i}+\mu_{i}
$$

Equation 2 presents the second model for a fixed asset:

$$
\begin{aligned}
{\text { Fixed } \text { asset }_{i}} & \alpha+\sum_{i=1}^{4} \beta_{2} \text { Age }_{i}+\sum_{i=1}^{3} \beta_{3} \text { Status }_{i}+\sum_{i=1}^{4} \beta_{4} E d u_{i}+\sum_{i=1}^{6} \beta_{5} \text { TB } \\
& +\mu_{i}+\beta_{6} \text { Loan }_{i}
\end{aligned}
$$

Equation 3 presents the third model for household expenditures:

\begin{tabular}{|c|c|}
\hline Variable Name & Description \\
\hline Fixed Assets difference & $\begin{array}{l}\text { The total amount of fixed assets before and after accessing loan from } \\
\text { the MFI }\end{array}$ \\
\hline Income difference & $\begin{array}{l}\text { Income of women businesses per month before and after accessing } \\
\text { loan from the MFI }\end{array}$ \\
\hline $\begin{array}{l}\text { Household Expenditures } \\
\text { difference }\end{array}$ & $\begin{array}{l}\text { The total amount of expenditure per month before and after accessing } \\
\text { loan from the MFI }\end{array}$ \\
\hline Age & $\begin{array}{l}\text { Enumerated variables: } \\
\text { 1: <30 years old; } \\
\text { 2: } 31-40 \text { years old; } \\
\text { 3: } 41-50 \text { years old; } \\
\text { 4: > 50 years old. }\end{array}$ \\
\hline Civil Status & $\begin{array}{l}\text { Enumerated variable } \\
\text { 1: married; } \\
\text { 2: single; } \\
\text { 3: widow. }\end{array}$ \\
\hline Educational Background & $\begin{array}{l}\text { Enumerated variable } \\
\text { 1: uneducated; } \\
\text { 2: primary school; } \\
\text { 3: secondary school; } \\
\text { 4: university or upper. }\end{array}$ \\
\hline TB & $\begin{array}{l}\text { A dummy variable of the nature of business } \\
\text { 1: food, 0: otherwise; } \\
\text { 2: agriculture, 0: otherwise; } \\
\text { 3: hairdressing (hair, makeup, aesthetic, massage etc.), 0: otherwise; } \\
\text { 4: education activity (language school, kindergarten, driving school, } \\
\text { etc.) 0: otherwise; } \\
\text { 5: textile (fashion designer), 0: otherwise; }\end{array}$ \\
\hline
\end{tabular}

$$
\begin{aligned}
\text { Expeditures }_{i}= & \alpha+\sum_{i=1}^{4} \beta_{2} \text { Age }_{i}+\sum_{i=1}^{3} \beta_{3} \text { Status }_{i}+\sum_{i=1}^{4} \beta_{4} \text { Edu }_{i}+\sum_{i=1}^{6} \beta_{5} \text { TB }_{i}+ \\
& \beta_{6} \text { Loan }_{i}+\beta_{7} \text { Growthincome }_{i}+\beta_{8} \text { Hohoincome }_{i}+\mu_{i}
\end{aligned}
$$

Table 1. Description of Determinants of Success of women businesses 


\begin{tabular}{ll}
\hline & 6: rental, 0: otherwise. \\
\hline Loan & The amount of loan accessed via the MFI \\
\hline Hoho income & Income of household per month \\
\hline Source: Prepared by the authe
\end{tabular}

Source: Prepared by the authors.

\section{Results and discussion}

As entrepreneurs, women in Kosovo's economy represent only $10 \%$ of business owners, mostly micro and small business owners. Today, entrepreneurship is valued as the driving force of economic development and sustainability. Entrepreneurship among women remains weak, with women less likely to start a business than men. Businesses initiated and managed by women are generally smaller. This is mainly because women face difficulties in accessing credit, information, markets and potential technologies, as they also face family obligations and social norms within their communities.

Women-owned enterprises promote organic and local products, for example food, hairdressing, aesthetic, textile industries are becoming increasingly important, making these businesses stand out, survive and, most importantly, have an impact.

Against the importance of developing women enterprises, finances remain their main challenge. Studies report that women who start and manage a business are largely financed by their own savings, and in some cases supplemented by financial institutions, while other forms such as inheritance capital, family budget and borrowing from friends and family are very small opportunities (Riinvest, 2017).

A woman's decision to open a business often comes as a result of the necessity to survive (Riinvest, 2017), rather than due to a personal aspiration. In addition, families' attitude towards entrepreneurship can have an impact not only on starting a business, but also on the overall business experience and performance, thus affecting the success or failure of business.

Women-owned businesses in Kosovo usually employ informal workers, have outdated equipment, and mainly specializes in traditional women's activities such as aesthetics, tailoring, flowers and food. According to reports (2019) by the Kosovo Agency of Statistics (KAS), women own less than $10 \%$ of businesses in Kosovo, face barriers beyond the usual ones in the market, and operate in sectors that do not offer growth opportunities.

Geographically, according to the Kosovo Business Registration Agency (KBRA), the geographical distribution of women enterprises in Kosovo is illustrated in Table 2.

Table 2. Distribution of women businesses by municipalities

\begin{tabular}{lc}
\hline Municipality & Percentage \\
\hline Prishtina & $38.3 \%$ \\
\hline Prizren & $10.9 \%$ \\
\hline Gjilan & $10.2 \%$ \\
\hline Ferizaj & $9.00 \%$ \\
\hline Peja & $8.3 \%$ \\
\hline Gjakova & $6.4 \%$ \\
\hline Vushtrri & $5.4 \%$ \\
\hline Podujevo & $4.8 \%$ \\
\hline Rahovec & $3.2 \%$ \\
\hline Mitrovica & $2.6 \%$ \\
\hline Lipjan & $0.6 \%$ \\
\hline Fushë Kosovo & $0.3 \%$
\end{tabular}

Source: Kosovo Business Registration Agency, 2018 
Table 3. presents the most popular activities of women entrepreneurs in Kosovo according to the KBRA, since we understand that women entrepreneurs are orientated towards activities that provide low income by creating a low profit margin.

Table 3. Most frequent activities among women's ownership enterprises

\begin{tabular}{lc}
\hline \multicolumn{1}{c}{ Sector } & Percentage \\
\hline Hair stylists and other beauty treatments & $29.2 \%$ \\
\hline Retail sale of clothing in specialised stores & $10.7 \%$ \\
\hline Manufacturing of clothes & $9.4 \%$ \\
\hline Retail sale of textiles in specialized stores & $9.1 \%$ \\
\hline Activities for organizing different events (and planning) & $3.9 \%$ \\
\hline Bread production; production of fresh cakes and pastries & $3.6 \%$ \\
\hline Education (driving schools, foreign language schools, etc.) & $2.9 \%$ \\
\hline Retail sale of goods in specialized stores (watches, jewellery, etc.) & $2.6 \%$ \\
\hline Retailing in non-specialized stores & $2.6 \%$ \\
\hline Source: Kosovo Business Registration Agency, 2018
\end{tabular}

Table 4 below demonstrates the analysis of women's businesses' performance, including fixed assets, income and household expenditures before receiving and after receiving a loan.

Table 4. The performance of women businesses accessing loan from the MFI

\begin{tabular}{|c|c|c|c|c|c|c|}
\hline & $\begin{array}{c}\text { Fixed assets } \\
\text { before accessing } \\
\text { loan }\end{array}$ & $\begin{array}{l}\text { Fixed assets } \\
\text { after accessing } \\
\text { the loan }\end{array}$ & $\begin{array}{l}\text { Income before } \\
\text { accessing loan }\end{array}$ & $\begin{array}{l}\text { Income after } \\
\text { accessing the } \\
\text { loan }\end{array}$ & $\begin{array}{l}\text { Household } \\
\text { expenditure } \\
\text { before } \\
\text { accessing } \\
\text { loan } \\
\end{array}$ & $\begin{array}{l}\text { Household } \\
\text { expenditure } \\
\text { after } \\
\text { accessing the } \\
\text { loan }\end{array}$ \\
\hline $\mathrm{N}$ & 200 & 200 & 200 & 200 & 200 & 200 \\
\hline Min & 0.00 & 800.00 & 0.00 & 250.00 & 300.00 & 450.00 \\
\hline Max & $16,000.00$ & $17,000.00$ & 2,000 & 3,500 & 700.00 & 950.00 \\
\hline Mean & $1,800.00$ & $1,850,00$ & 650.00 & 738.00 & 420.00 & 480.00 \\
\hline Median & 35 & 50 & 55 & 80 & 66 & 33 \\
\hline $\begin{array}{l}\text { Standard } \\
\text { deviation }\end{array}$ & 41960.6 & 111777.2 & 13103.35 & 16447.29 & 1100.43 & 1213.27 \\
\hline
\end{tabular}

Source: Authors' calculations.

From Table 4, we see that there were entrepreneurs who started their business with the help of credit, but also entrepreneurs who had businesses but needed financial means and were forced to borrow. We conclude that there are improvements in women businesses' fixed assets, income and household expenses before and after receiving lending. It could also be concluded that the women businesses can raise their assets, income and household expenses after receiving loans from the MFI.

The minimum of household expenses indicates that only minor improvements have occurred after obtaining the loan. This is in contrast with the maximum of household expenses, as the former shows that it has increased drastically after receiving the loan. It came after a number of women entrepreneurs stated that they use the business income for business needs while taking out loans to cover household expenses.

Table 5 shows the results for the factors that determine the success of women businesses that receive loans from the MFI in terms of women businesses' fixed assets, income and 
household expenditure. In this respect, regression (I) analyses factors that determine the success of women businesses in terms of fixed assets; regression (II) concentrates on the factors that determine the success of women businesses in terms of income of the enterprise and regression (III) analyses factors that determine the success of women businesses measured by household expenditure.

Table 5. Effect of loan on performance of women businesses.

\begin{tabular}{|c|c|c|c|}
\hline & $\begin{array}{c}\text { Difference in Fixed } \\
\text { Assets }\end{array}$ & Difference in Income & Difference in Household Expenditures \\
\hline Regression & (Regression I) & (Regression II) & (Regression III) \\
\hline Age & $\begin{array}{c}7.07 \\
(10.93) \\
\end{array}$ & $\begin{array}{l}-1.34 \\
(3.54) \\
\end{array}$ & $\begin{array}{c}0.29 \\
(0.35) \\
\end{array}$ \\
\hline Civil Status & $\begin{array}{c}10.56 \\
(45.06) \\
\end{array}$ & $\begin{array}{c}-15.12 \\
(11.35) \\
\end{array}$ & $\begin{array}{c}1.25 \\
(2.11) \\
\end{array}$ \\
\hline Education & $\begin{array}{c}16.12 \\
(23.11) \\
\end{array}$ & $\begin{array}{l}10.32 \\
(6.26) \\
\end{array}$ & $\begin{array}{c}0.11 \\
(0.69) \\
\end{array}$ \\
\hline Loan & $\begin{array}{l}19.13^{*} \\
(38.21) \\
\end{array}$ & $\begin{array}{c}134.11 * \\
(10.82)\end{array}$ & $\begin{array}{l}11.93^{*} \\
(10.59) \\
\end{array}$ \\
\hline Food & $\begin{array}{c}4.42 \\
(135.87) \\
\end{array}$ & $\begin{array}{l}22.45^{*} \\
(15.21) \\
\end{array}$ & \\
\hline Agriculture & $\begin{array}{c}-8.89 \\
(139.57) \\
\end{array}$ & $\begin{array}{r}108.45 \\
(65.72) \\
\end{array}$ & \\
\hline Hairdressing & $\begin{array}{c}33.74 \\
(160.63) \\
\end{array}$ & $\begin{array}{l}27.13^{*} \\
(13.63) \\
\end{array}$ & \\
\hline Education activity & $\begin{array}{c}-43.74 \\
(170.33) \\
\end{array}$ & $\begin{array}{c}21.11 \\
(12.69) \\
\end{array}$ & \\
\hline Textile & $\begin{array}{c}21.2 \\
(144.97)\end{array}$ & $\begin{array}{c}19.2 * \\
(12.23)\end{array}$ & \\
\hline
\end{tabular}

Hoho income

$-0.11$

$(0.23)$

\begin{tabular}{lccc} 
Rental & 12.74 & 11.55 & \\
& $(157.38)$ & $(17.21)$ & 0.04 \\
$R^{2}$ & 0.09 & 0.06 & 200 \\
Observations & 200 & 200 & 1.38 \\
D-W & 1.43 & 1.07 & \\
\hline
\end{tabular}

Notes: Under F-statistics the P-values are given in parentheses. Standard errors are also given in parentheses under coefficients. Individual coefficients are significant at the $10 \%$ significance level.

Regression (I), (II), and (III) indicate heteroscedasticity and are free from autocorrelation, all of the coefficients in regression (I), (II), and (III) have been transformed into heteroscedasticity-robust standard errors. 
Regression (I) analyses factors that determine the success of women businesses that receive loans measured by fixed assets. Business characteristics such as age, civil status, and education indicate an insignificant relationship with fixed assets difference. Regression (I) also shows that financing in terms of amount of loan accessed has an influence on the success of women businesses in terms of fixed assets difference. If the loan amount obtained from the MFI increases by $1 \%$, this increases the fixed assets difference by $0.19 \%$.

Regression (II) analyses factors that determine the success of women businesses that receive loans measured by income. Business characteristics such as age, civil status and education indicate a positive relationship with the difference in income of women businesses. The log amount of loan on the other hand indicates a positive significant relationship with difference in income. It shows that if the amount of loan obtained from the MFI increases by $1 \%$, this increases the change in income by $1.34 \%$ per month.

The business characteristic in regard to the variable of hairdressing indicates a positive significant relationship with difference in income. This shows that hairdressing businesses have a $27.13 \%$ higher difference in income, which is more than others. After hairdressing business there is the variable of food, which indicates a positive significant relationship with change in income. This shows that food businesses have a $22.45 \%$ higher change in income.

Regression (III) analyses factors that determine the success of women businesses that receive loans measured by household expenditures. None of the business characteristics in terms of age, civil status and education indicate a positive relationship with the difference in income of women businesses. This regression shows that financing in terms of amount of loan indicates a positive significant relationship with difference in household expenditure. The rise of the loan by $1 \%$ rises the difference in household expenditure by around $0.11 \%$.

Business characteristics such as age, civil status and education indicate a positive significant relationship with difference in household expenditure. This is followed by household characteristics in terms of household income. Therefore, all of the variables are free from multicollinearity in regression (III).

R-squared (R2) values in the regression (I), (II), and (III) were considered low, namely $0.09,0.06$, and 0.04 . The low values of $\mathrm{R} 2$ in the analysis are not relevant because the data came from a variety of women entrepreneurs, some of whom accessed small loans, while some accessed large loans. Some of the women entrepreneurs were new clients, while some were old clients. Moreover, some of the women entrepreneurs had established enterprises before accessing a loan, while some women entrepreneurs became more financially stable after accessing a loan. Further, some women entrepreneurs did not achieve any improvements in their business performances after accessing a loan.

\section{Conclusion}

From this research we can see that the majority of women businesses are small in nature - a category that predominates in Kosovo. Although women's businesses have received loans, the loans have been small reflecting a larger impact on their business or even an increase in the number of employees. Loan targeting has been classified into three categories that have served women entrepreneurs: destination for fixed asset growth, destination for income growth and destination for family expenses. Given that the amounts financed by the MFI are small, this reflects a small $0.19 \%$ impact value on the growth of fixed assets, but this has not had an impact on revenue growth, as asset growth has a higher impact, with a value of $1.34 \%$. Hairdressing businesses and food businesses have shown the greatest impact in the income category.

The results of this study explain that loans from the MFI have a positive effect on the performance of women businesses through fixed assets, income and household expenses. 
It is therefore recommended that the Kosovo government subsidies a funding cut for women in order to increase the amount of funding, which would in turn increase the impact of women's business development and affect the well-being of these women and their families.

\section{References}

Alkire, S., Meinzen-Dick, R., Peterman, A., Quisumbing, A., Seymour, G., \& Vaz, A. (2013). The women's empowerment in agriculture index. World Development, 52, 71-91.

ARBK. (2018). Kosovo Business Registration Agency.

Bashar, T., \& Rashid, S. (2012). Urban microfinance and urban poverty in Bangladesh. Journal of the Asia Pacific Economy, 17(1), 151-170.

Bonfiglioli, C. (2016). The first UN world conference on women (1975) as a cold war encounter: Recovering anti-imperialist, non-aligned and socialist genealogies. Filozofija i društvo, 27(3), 521-541.

Bonfiglioli, C., Epstein, A., \& Fuchs, R. G. (2016). Cold War Gendered Imaginaries of Citizenship and Transnational Women's Activism: The Case of the Movie Die Windrose (1957). Gender and Citizenship in Historical and Transnational Perspective: Agency, Space, Borders, 166.

Brahmachary, A. (2017). Microfinance for Women-Owned Small Business in India: Challenges and Opportunities. In Women's Entrepreneurship and Microfinance (pp. 131-153). Springer, Singapore.

Ferdousi, F. (2015). Impact of microfinance on sustainable entrepreneurship development. Development Studies Research, 2(1), 51-63.

Ferdousi, F., \& Mahmud, P. (2019). Role of social business in women entrepreneurship development in Bangladesh: perspectives from Nobin Udyokta projects of Grameen Telecom Trust. Journal of Global Entrepreneurship Research, 9(1), 1-21.

Ferdousi, F., Shi Cun, X., \& Mostak, A. G. (2012). Impact of micro-credit loans on income and innovation: evidence from Bangladesh. In In Proceedings of the 9th International Conference on Innovation and Management, Eindhoven, The Netherlands, November (pp. 14-16).

Fetsch, E., Jackson, C., \& Wiens, J. (2015). Women entrepreneurs are key to accelerating growth. Kauffman Foundation.

Fidrmuc, J., Kostagianni, S. (2015). Impact of IMF Assistance on Economic Growth Revisited, Economics and Sociology, 8(3), 32-40. doi:10.14254/2071-789X.2015/8-3/2

Grootaert, C., Narayan, D., Jones, V. N., \& Woolcock, M. (2003). Integrated questionnaire for the measurement of social capital. The World Bank Social Capital Thematic Group.

Hughes, K. D. (2006). Exploring motivation and success among Canadian women entrepreneurs. Journal of Small Business \& Entrepreneurship, 19 (2), 107-120.

Instituti Riinvest. (2017). Ndërmarrësia e Grave - Analiza e të bërit biznës në Kosovë.

International Monetary Fund. (2019). Finance and development. Volume 56, Number 1.

Khaleque, A. (2018). Performance of women entrepreneurs: Does access to finance really matter? Eurasian Journal of Business and Economics, 11(21), 23-48.

Khan, I., Abdullah, M. F., Rahman, N. N. A., Nor, M. R. B. M., \& Yusoff, M. Y. Z. B. M. (2016). The right of women in property sharing in Bangladesh: Can the islamic inheritance system eliminate discrimination?. SpringerPlus, 5(1), 1-8.

Kosovo Agency of Statistics. (2019). Annual reports.

Krishna, A. (2003). Social Capital, Community Driven Development, and Empowerment: A short note on concepts and operations. World Bank working paper, 33077. 
Mahmud, K. T., Parvez, A., Alom, K., Bakshi, R. K., \& Khan, M. A. (2019). Impact of monthly repayment system on the household healthcare expenditure of the rural women borrowers: evidence from Bangladesh. Journal of Poverty, 23(5), 365-383

Mahmud, S., \& Bidisha, S. H. (2018). Female labor market participation in Bangladesh: Structural changes and determinants of labor supply. In S. Raihan (Ed.), Structural Change and Dynamics of Labor Markets in Bangladesh. Singapore: South Asia Economic and Policy Studies. Springer.

Malhotra, A., Schuler, S. R., \& Boender, C. (2002, June). Measuring women's empowerment as a variable in international development. In background paper prepared for the World Bank Workshop on Poverty and Gender: New Perspectives (Vol. 28).

Quagrainie, F.A., Opoku Mensah, A., \& Adom, A.Y. (2018). Christian entrepreneurial activities and micro women entrepreneurship development: Church embeddedness in action. Journal of Enterprising Communities: People and Places in the Global Economy, 12(5), 657-676. https://doi.org/10.1108/JEC-03-2018-0025

Shkodra, J. (2019). Financial performance of microfinance institutions in Kosovo. Journal of International Studies, 12(3), 31-37.

Shkodra, J., \& Shkodra, L. (2018). Impact of agricultural finance in rural areas-case study Kosovo. Bulgarian Journal of Agricultural Science, 24(5), 737-741.

Swain, R. B., \& Wallentin, F. Y. (2009). Does microfinance empower women? Evidence from self-help groups in India. International review of applied economics, 23(5), 541-556.

Swapna, K. (2017). Impact of microfinance on women entrepreneurship. International Journal of Business Administration and Management, 7(1), 2278-3660.

Tariq, S. (2019). Impact of microfinance on women entrepreneurship. Arabian Journal of Business and Management Review (Oman Chapter), 8(1), 7-16.

Uddin, J., Pulok, M. H., \& Sabah, M. N. (2016). Correlates of unmet need for contraception in Bangladesh: Does couples' concordance in household decision making matter? Contraception, 94(1), 18-26. 